\title{
Article \\ Antibacterial Secondary Metabolites from Marine-Derived Fungus Aspergillus sp. IMCASMF180035
}

\author{
Fuhang Song ${ }^{1, * \mathbb{D}}$, Rui Lin ${ }^{2}$, Na Yang ${ }^{3,4}$, Jia Jia ${ }^{5}$, Shangzhu Wei ${ }^{2}$, Jiahui Han ${ }^{2}$, Jiangpeng Li ${ }^{2}$, Hongkai Bi $^{5} \mathbb{D}$ \\ and Xiuli $\mathrm{Xu}{ }^{2, *}$
}

check for

updates

Citation: Song, F.; Lin, R.; Yang, N.; Jia, J.; Wei, S.; Han, J.; Li, J.; Bi, H.; Xu, $X$. Antibacterial Secondary Metabolites from Marine-Derived Fungus Aspergillus sp. IMCASMF180035. Antibiotics 2021, 10, 377. https://doi.org/10.3390/ antibiotics 10040377

Academic Editor: Gary A. Strobel

Received: 28 February 2021

Accepted: 1 April 2021

Published: 3 April 2021

Publisher's Note: MDPI stays neutral with regard to jurisdictional claims in published maps and institutional affiliations.

Copyright: (c) 2021 by the authors. Licensee MDPI, Basel, Switzerland. This article is an open access article distributed under the terms and conditions of the Creative Commons Attribution (CC BY) license (https:/ / creativecommons.org/licenses/by/ $4.0 /)$.
1 School of Light Industry, Beijing Technology and Business University, Beijing 100048, China

2 School of Ocean Sciences, China University of Geosciences, Beijing 100083, China; linrui520@126.com (R.L.); wert0715@163.com (S.W.); 15632779760@163.com (J.H.); culjp2016@163.com (J.L.)

3 CAS Key Laboratory of Experimental Marine Biology, Institute of Oceanology, Chinese Academy of Sciences, Qingdao 266071, China; yangna@qdio.ac.cn

4 Laboratory for Marine Biology and Biotechnology, Qingdao National Laboratory for Marine Science and Technology, Qingdao 266071, China

5 Department of Pathogen Biology, Jiangsu Key Laboratory of Pathogen Biology, Nanjing Medical University, Nanjing 211166, China; jiajia@njmu.edu.cn (J.J.); hkbi@njmu.edu.cn (H.B.)

* Correspondence: songfuhang@btbu.edu.cn (F.S.); xuxl@cugb.edu.cn (X.X.)

\begin{abstract}
Four new secondary metabolites, including one spiro[anthracenone-xanthene] derivative aspergiloxathene $\mathrm{A}(\mathbf{1})$, one penicillide analogue, $\Delta^{2^{\prime}}-1^{\prime}$-dehydropenicillide (2), and two new phthalide derivatives, 5-methyl-3-methoxyepicoccone (3) and 7-carboxy-4-hydroxy-6-methoxy-5methylphthalide (4), together with four known compounds, yicathin C (5), dehydropenicillide (6), 3-methoxyepicoccone (7), 4-hydroxy-6-methoxy-5-methylphthalide (8), were identified from the marine-derived fungus Aspergillus sp. IMCASMF180035. Their structures were determined by spectroscopic data, including high-resolution electrospray ionization mass spectrometry (HRESIMS), 1D and 2D nuclear magnetic resonance (NMR) techniques. Compound $\mathbf{1}$ was identified as the first jointed molecule by xanthene and anthracenone moieties possessing an unprecedented carbon skeleton with spiro-ring system. All compounds were evaluated activities against Staphylococcus aureus, methicillin resistant S. aureus (MRSA), Escherichia coli, Escherichia faecium, Pseudomonas aeruginosa, and Helicobacter pylori. Compound $\mathbf{1}$ showed significant inhibitory effects against $S$. aureus and MRSA, with minimum inhibitory concentration (MIC) values of 5.60 and $22.40 \mu \mathrm{M}$. Compounds 2 and 6 exhibited potent antibacterial activities against $H$. pylori, with MIC values of 21.73 and $21.61 \mu \mathrm{M}$, respectively.
\end{abstract}

Keywords: marine-derived fungus; Aspergillus sp.; natural products; anti-Staphylococcus aureus; anti-Helicobacter pylori

\section{Introduction}

Overuse of antibiotics has led to the emergence and maintenance of drug resistance. The ESKAPE (Enterococcus faecium, Staphylococcus aureus, Klebsiella pneumoniae, Acinetobacter baumanii, Pseudomonas aeruginosa, and Enterobacter species) pathogens are responsible for a variety of infectious diseases with a wide range of drug resistance to current clinical drugs [1]; therefore, there is urgent need to develop novel antibiotics [2,3]. Natural products have historically played an important role in the development of novel antibacterial agents [4]. Natural products characterized from marine-derived organisms are considered more and more important for drug development [5-7]. In recent years, more than 1000 new compounds were identified from organisms living in marine habitats per annum [8-10], which suggests the great potential of discovering new chemical entries from marine-derived organisms.

Fungi of the Aspergillus genus isolated from a marine environment have been proven to be rich sources for discovering new chemical entries with antibacterial and antifun- 
gal [11-18], inflammatory [19], antiviral [20,21], and antitumor [22,23] activities. During our ongoing search for novel bioactive secondary metabolites against bacteria and mycobacteria from marine-derived fungi, the crude extract of the fungus Aspergillus sp. IMCASMF180035, isolated from a sediment sample collected from the intertidal zones of the Yellow Sea in Qingdao, China, showed antibacterial activity against $S$. aureus with a minimum inhibitory concentration (MIC) value of $25 \mu \mathrm{g} / \mathrm{mL}$. Further chemical investigation on the ethyl acetate extract led to the identification of eight natural products (Figure 1), including four new secondary metabolites, aspergiloxathene A (1), $\Delta^{2^{\prime}}-1^{\prime}$-dehydropenicillide (2), 5-methyl-3-methoxyepicocc- one (3), and 7-carboxy-4hydroxy-6-methoxy-5-methylphthalide (4), together with four known compounds, yicathin C (5), 1'-dehydropenicillide (6), 3-methoxyepicoccone (7), and 4-hydroxy-6-methoxy-5methylphthalide (8). To the best of our knowledge, aspergiloxathene A (1) is the first natural product with xanthene and anthracenone fragments possessing an unprecedented carbon skeleton with a spiro-ring system. Herein, we report the isolation, structural elucidation, and biological activities of these compounds.<smiles>Cc1cc(C)c2c(c1O)C(=O)c1c(O)cc(O)cc1[C@@]21c2c(cc(O)c(O)c2O)Oc2c(O)c(O)cc(C)c21</smiles>

1<smiles>COc1cc(C(=O)O)cc2oc3cc(C)cc(O)c3c(=O)c12</smiles>

5<smiles>COc1c(O)c(C)c2c(c1O)C(OC)OC2=O</smiles>
3<smiles>COC1OC(=O)c2c(C)c(O)c(O)c(O)c21</smiles><smiles>COc1c(C)c(O)c2c(c1C(=O)O)C(=O)OC2</smiles><smiles>COc1cc2c(c(O)c1C)COC2=O</smiles>

Figure 1. Chemical structures of 1-8.

\section{Results and Discussion}

\subsection{Culture of Fungus and Isolation of Compounds}

Aspergillus sp. IMCASMF180035 was inoculated into $1 \mathrm{~L}$ flasks with rice solid medium and incubated stationary at $28^{\circ} \mathrm{C}$ for 30 days. The cultures and medium were extracted by EtOAc:MeOH and followed by a series of purification methods, such as partition, reduced normal phase silica chromatography, Sephadex LH-20 chromatography, and highperformance liquid chromatography according to our previous report $[11,12]$ to yield compounds 1-8.

\subsection{Structure Elucidation}

Compound 1 was isolated as a light yellow powder. The molecular formula of $\mathbf{1}$ was determined to be $\mathrm{C}_{30} \mathrm{H}_{22} \mathrm{O}_{11}$ based on the high-resolution electrospray ionization mass spectrometry (HRESIMS) spectrum $\left(m / z[\mathrm{M}+\mathrm{H}]^{+} 559.1235\right.$, calcd for $\left.\mathrm{C}_{30} \mathrm{H}_{22} \mathrm{O}_{11}{ }^{+}, 559.1235\right)$, accounting for 20 degrees of unsaturation (Supplementary Figure S1). The ${ }^{1} \mathrm{H}$ NMR and ${ }^{1} \mathrm{H}-{ }^{1} \mathrm{H}$ correlation spectroscopy data of $\mathbf{1}$ (Table 1 and Supplementary Figures S2 and S5) demonstrated four aromatic signals at $\delta_{\mathrm{H}} 6.28(1 \mathrm{H}, \mathrm{s}, \mathrm{H}-4), 5.90(1 \mathrm{H}, \mathrm{d}, J=2.0 \mathrm{~Hz}, \mathrm{H}-5)$, $6.19(1 \mathrm{H}, \mathrm{d}, J=2.0 \mathrm{~Hz}, \mathrm{H}-7)$, and $6.15\left(2 \mathrm{H}, \mathrm{s}, \mathrm{H}-2^{\prime}\right.$, and $\left.\mathrm{H}-7^{\prime}\right)$; three methyl groups at $\delta_{\mathrm{H}} 2.10$ $(3 \mathrm{H}, \mathrm{s}, \mathrm{H}-12)$ and $1.34\left(6 \mathrm{H}, \mathrm{s}, \mathrm{H}-9^{\prime}\right.$, and $\left.\mathrm{H}-10^{\prime}\right)$; and four phenolic hydroxyl groups at $\delta_{\mathrm{H}} 9.90$ $\left(2 \mathrm{H}, \mathrm{s}, 4^{\prime}-\mathrm{OH}\right.$, and $\left.5^{\prime}-\mathrm{OH}\right)$ and $8.95\left(2 \mathrm{H}, \mathrm{s}, 3^{\prime}-\mathrm{OH}\right.$, and $\left.6^{\prime}-\mathrm{OH}\right)$. The ${ }^{13} \mathrm{C}$ and heteronuclear single quantum coherence (HSQC) spectrum of 1 (Supplementary Figures S3 and S4) 
indicated 30 carbons signals (Table 1 ) for one carbonyl at $\delta_{\mathrm{C}} 190.2$ (C-10); one carboxyl at $\delta_{\mathrm{C}} 167.5$ (C-11); five sp ${ }^{2}$ methine carbons at $\delta_{\mathrm{C}} 123.5$ (C-4), 111.7 (C-5), 115.5 (C-2' and C-7'), and 101.3 (C-7); nineteen $\mathrm{sp}^{2}$ quaternary carbons at $\delta_{\mathrm{C}} 165.6$ (C-6), 163.3 (C-8), 156.6 (C1), 153.5 (C-4b), 150.6 (C-4a), 144.1 (C-3' and C-6'), 143.2 (C-3), 137.3 (C-4'a and C-4'b), 131.0 (C-4' and C-5'), 125.9 (C-1' and C-8'), 122.6 (C-2), 114.1 (C-8b), 117.7 (C-8'a and C-8'b), and 109.7 (C-8a); one sp ${ }^{3}$ quaternary carbon at $\delta_{\mathrm{C}} 45.6$ (C-9); and three methyl carbons at $\delta_{\mathrm{C}} 19.9$ (C-9' and C-10') and 19.8 (C-12). All these NMR data suggest that compound 1 contained a multihydroxyl-substituted aromatic compound. The heteronuclear multiple bond correlation (HMBC) correlations (Figure 2 and Supplementary Figures S6-S8) from $\mathrm{H}-4$ to $\mathrm{C}-2, \mathrm{C}-8 \mathrm{~b}$, and $\mathrm{C}-12$ and from $\mathrm{H}-12$ to $\mathrm{C}-2, \mathrm{C}-3$, and $\mathrm{C}-4$ revealed the moiety of ring $\mathrm{A}$. The HMBC correlations from $\mathrm{H}-5$ to $\mathrm{C}-4 \mathrm{~b}, \mathrm{C}-6, \mathrm{C}-7$, and $\mathrm{C}-8 \mathrm{a}$ and from $\mathrm{H}-7$ to C-5, C-6, C-8, and C-8a indicated the substructure of ring B. The HMBC correlations from $\mathrm{H}-4$ and $\mathrm{H}-5$ to C-9 and the long-range HMBC correlations from $\mathrm{H}-4$ and $\mathrm{H}-5$ to $\mathrm{C}-10$ suggested that ring $A$ and ring $B$ are connected through $C-10$ and $C-9$, as shown in Figure 2. From the integration of $\mathrm{H}-2^{\prime} / \mathrm{H}-\mathrm{7}^{\prime}, \mathrm{H}-3^{\prime} / \mathrm{H}-6^{\prime}-\mathrm{OH}, \mathrm{H}-4^{\prime} / \mathrm{H}-5^{\prime}-\mathrm{OH}$, and $\mathrm{H}-9^{\prime}$ and $\mathrm{H}-10^{\prime}$, moiety $\mathrm{C}$ was deduced as a symmetric substructure. The key HMBC correlations from $\mathrm{H}-2^{\prime} / \mathrm{H}-7^{\prime}$ to C-3' /C-6', C-4' /C-5', C-8'b/C-8'a, and C-9' /C-10' and from H-9' /H-10' to $\mathrm{C}-1^{\prime} / \mathrm{C}-8^{\prime}, \mathrm{C}-2^{\prime} / \mathrm{C}-7^{\prime}$, and $\mathrm{C}-8^{\prime} \mathrm{b} / \mathrm{C}-8^{\prime} \mathrm{a}$ indicated the presence of moiety $\mathrm{C}$. The long-range $\mathrm{HMBC}$ correlations from $\mathrm{H}-2^{\prime} / \mathrm{H}-7^{\prime}$ to $\mathrm{C}-9$ suggested the connections of $\mathrm{C}-9$ to $\mathrm{C}-8^{\prime} \mathrm{a}$ and C-8'b. The HMBC crossing peaks from $\mathrm{H}-3^{\prime}-\mathrm{OH} / \mathrm{H}-6^{\prime}-\mathrm{OH}$ to $\mathrm{C}-2^{\prime} / \mathrm{C}-7^{\prime}, \mathrm{C}-3^{\prime} / \mathrm{C}-6^{\prime}$, and $\mathrm{C}-4^{\prime} / \mathrm{C}-5^{\prime}$ and from $\mathrm{H}-4^{\prime}-\mathrm{OH} / \mathrm{H}-5^{\prime}-\mathrm{OH}$ to $\mathrm{C}-3^{\prime} / \mathrm{C}-6^{\prime}, \mathrm{C}-4^{\prime} / \mathrm{C}-5^{\prime}$, and $\mathrm{C}-4 \mathrm{a}^{\prime} / \mathrm{C}-4 \mathrm{~b}^{\prime}$ revealed the positions of the hydroxyl groups of substructure $\mathrm{C}$. The two rings of the xanthene fragment showed symmetry through a plane of the anthracenone fragment by running Minimize Energy in ChemBio 3D, which was consisted with the zero of optical rotation for $\mathbf{1}$. As a result, the structure of compound $\mathbf{1}$ was assigned as shown in Figure 1 and named as aspergiloxathene $\mathrm{A}$.

Table 1. ${ }^{1} \mathrm{H}(500 \mathrm{MHz})$ and ${ }^{13} \mathrm{C}(125 \mathrm{MHz})$ nuclear magnetic resonance (NMR) data of $\mathbf{1}$ and 2.

\begin{tabular}{|c|c|c|c|c|c|}
\hline \multirow{2}{*}{ Position } & \multicolumn{2}{|c|}{$1\left(\mathrm{DMSO}-d_{6}\right)$} & \multirow{2}{*}{ Position } & \multicolumn{2}{|c|}{$2\left(\mathrm{CDCl}_{3}\right)$} \\
\hline & $\delta_{C}$, Type & $\delta_{H}(J$ in $\mathbf{H z})$ & & $\delta_{C}$, Type & $\delta_{H}(J$ in $\mathrm{Hz})$ \\
\hline 1 & 156.6, C & & 1 & 118.0, $\mathrm{CH}$ & $6.94(\mathrm{~d}, J=8.5 \mathrm{~Hz})$ \\
\hline 2 & 122.6, C & & 2 & $134.8, \mathrm{CH}$ & $7.72(\mathrm{~d}, J=8.5 \mathrm{~Hz})$ \\
\hline 3 & $143.2, \mathrm{C}$ & & 3 & 134.0, C & \\
\hline 4 & $123.5, \mathrm{CH}$ & $6.28(\mathrm{~s})$ & 4 & $156.9, \mathrm{C}$ & \\
\hline $4 a$ & $150.6, \mathrm{C}$ & & $4 a$ & 121.6, C & \\
\hline $4 b$ & $153.5, \mathrm{C}$ & & 5 & $166.4, \mathrm{C}$ & \\
\hline 5 & 111.7, $\mathrm{CH}$ & $5.90(\mathrm{~d}, J=2.0 \mathrm{~Hz})$ & 7 & $69.1, \mathrm{CH}_{2}$ & $5.11(\mathrm{~s})$ \\
\hline 6 & $165.6, \mathrm{C}$ & & $7 a$ & $125.9, \mathrm{C}$ & \\
\hline 7 & $101.3, \mathrm{CH}$ & $6.19(\mathrm{~d}, J=2.0 \mathrm{~Hz})$ & 8 & $121.2, \mathrm{CH}$ & $6.40(\mathrm{~s})$ \\
\hline 8 & $163.3, \mathrm{C}$ & & 9 & $135.6, \mathrm{C}$ & \\
\hline $8 a$ & 109.7, C & & 10 & $117.8, \mathrm{CH}$ & $6.87(\mathrm{~s})$ \\
\hline $8 b$ & $114.1, \mathrm{C}$ & & 11 & $147.4, \mathrm{C}$ & \\
\hline 9 & $45.6, \mathrm{C}$ & & $11 \mathrm{a}$ & 141.0, C & \\
\hline 10 & $190.2, \mathrm{C}$ & & $12 \mathrm{a}$ & 154.0, C & \\
\hline 11 & $167.5, \mathrm{C}$ & & 13 & $64.3, \mathrm{CH}_{3}$ & $3.91(\mathrm{~s})$ \\
\hline 12 & $19.8, \mathrm{CH}_{3}$ & $2.10(\mathrm{~s})$ & $1^{\prime}$ & $190.7, \mathrm{C}$ & \\
\hline $1^{\prime} / 8^{\prime}$ & $125.9, \mathrm{C}$ & & $2^{\prime}$ & $124.1, \mathrm{CH}$ & $6.66(\mathrm{~s})$ \\
\hline $2^{\prime} / 7^{\prime}$ & $115.5, \mathrm{CH}$ & $6.15(\mathrm{~s})$ & $3^{\prime}$ & $158.8, \mathrm{C}$ & \\
\hline $3^{\prime} / 6^{\prime}$ & 144.1, C & & $4^{\prime}$ & 21.7, $\mathrm{CH}_{3}$ & $2.26(\mathrm{~s})$ \\
\hline $4^{\prime} / 5^{\prime}$ & 131.0, C & & $5^{\prime}$ & $28.3, \mathrm{CH}_{3}$ & $2.01(\mathrm{~s})$ \\
\hline $4^{\prime} \mathrm{a} / 4^{\prime} \mathrm{b}$ & 137.3, C & & $1^{\prime \prime}$ & $21.0, \mathrm{CH}_{3}$ & $2.25(\mathrm{~s})$ \\
\hline $8^{\prime} \mathrm{a} / 8^{\prime} \mathrm{b}$ & $117.7, \mathrm{C}$ & & & & \\
\hline $9^{\prime} / 10^{\prime}$ & $19.9, \mathrm{CH}_{3}$ & $1.34(\mathrm{~s})$ & & & \\
\hline $3^{\prime} / 6^{\prime}-\mathrm{OH}$ & & $8.95(\mathrm{~s})$ & & & \\
\hline $4^{\prime} / 5^{\prime}-\mathrm{OH}$ & & $9.00(\mathrm{~s})$ & & & \\
\hline
\end{tabular}



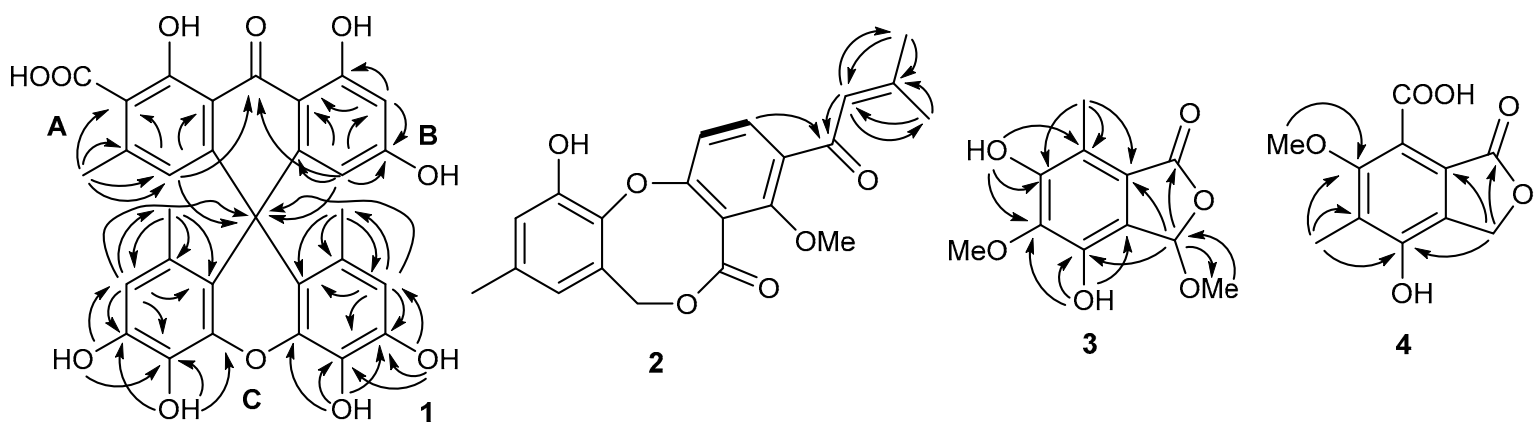

Figure 2. ${ }^{1} \mathrm{H}-{ }^{1} \mathrm{H}$ correlation spectroscopy $\left({ }^{1} \mathrm{H}_{-}{ }^{1} \mathrm{H}\right.$ COSY) and key heteronuclear multiple bond correlation (HMBC) correlations of $\mathbf{1}-\mathbf{4}$.

Compound $\mathbf{2}$ was isolated as a light yellow powder. The molecular formula of $\mathbf{1}$ was determined to be $\mathrm{C}_{21} \mathrm{H}_{20} \mathrm{O}_{6}$ based on the HRESIMS spectrum $(\mathrm{m} / z \text { [M }+\mathrm{H}]^{+} 369.1330$, calcd for $\mathrm{C}_{21} \mathrm{H}_{21} \mathrm{O}_{6}{ }^{+}, 369.1333$ ), accounting for twelve degrees of unsaturation (Supplementary Figure S10). The ${ }^{1} \mathrm{H}$ NMR data of 2 (Table 1 and Supplementary Figure S11) demonstrated two ortho aromatic signals at $\delta_{\mathrm{H}} 6.94(1 \mathrm{H}, \mathrm{d}, J=8.5 \mathrm{~Hz}, \mathrm{H}-1)$ and $7.72(1 \mathrm{H}, \mathrm{d}, J=8.5 \mathrm{~Hz}, \mathrm{H}-2)$, two singlet aromatic protons at $\delta_{\mathrm{H}} 6.40(1 \mathrm{H}, \mathrm{s}, \mathrm{H}-8)$ and $6.87(1 \mathrm{H}, \mathrm{s}, \mathrm{H}-10)$, and one olefinic proton at $\delta_{\mathrm{H}} 6.66\left(1 \mathrm{H}, \mathrm{s}, \mathrm{H}-2^{\prime}\right)$. In addition, one oxygenated methylene at $\delta_{\mathrm{H}} 5.11(2 \mathrm{H}, \mathrm{brs}$, $\mathrm{H}-7)$; one methoxyl group at $\delta_{\mathrm{H}} 3.91(3 \mathrm{H}, \mathrm{s}, \mathrm{H}-13)$; and three methyl groups at $\delta_{\mathrm{H}} 2.26(3 \mathrm{H}$, $\left.\mathrm{s}, \mathrm{H}-4^{\prime}\right), 2.01\left(3 \mathrm{H}, \mathrm{s}, \mathrm{H}-5^{\prime}\right)$, and $2.25\left(3 \mathrm{H}, \mathrm{s}, \mathrm{H}-1^{\prime \prime}\right)$ were observed in the proton spectrum. The ${ }^{13} \mathrm{C}$ and HSQC spectrum of 2 (Supplementary Figures S12 and S13) showed 21 carbons signals (Table 1), including one carbonyl at $\delta_{\mathrm{C}} 190.7\left(\mathrm{C}-1^{\prime}\right)$; one carboxyl at $\delta_{\mathrm{C}} 166.4(\mathrm{C}-5)$; five $\mathrm{sp}^{2}$ methine carbons at $\delta_{\mathrm{C}} 118.0(\mathrm{C}-1), 134.8(\mathrm{C}-2), 121.2(\mathrm{C}-8), 117.8(\mathrm{C}-10)$, and 124.1 (C-2'); nine sp ${ }^{2}$ quaternary carbons at $\delta_{\mathrm{C}} 134.0$ (C-3), 156.9 (C-4), 121.6 (C-4a), 125.9 (C-7a), 135.6 (C-9), 147.4 (C-11), 141.0 (C-11a), 154.0 (C-12a), and 158.8 (C-3'); one oxygenated methylene carbon at $\delta_{\mathrm{C}} 69.1$ (C-7); one methoxyl carbon at $\delta_{\mathrm{C}} 64.3$ (C-13); and three methyl carbons at $\delta_{\mathrm{C}} 21.7\left(\mathrm{C}-4^{\prime}\right), 28.3\left(\mathrm{C}-5^{\prime}\right)$, and $21.0\left(\mathrm{C}-1^{\prime \prime}\right)$. A detailed analysis of the $1 \mathrm{D}$ and 2D NMR data (Figure 2 and Supplementary Figures S11-S15) indicated that 2 is an analogue of penicillide [24]. In the HMBC spectra, the correlations from $\mathrm{H}-4^{\prime}$ and $\mathrm{H}-5^{\prime}$ to $\mathrm{C}-2^{\prime}\left(\delta_{\mathrm{C}} 124.1\right)$ and $\mathrm{C}-3^{\prime}\left(\delta_{\mathrm{C}} 158.8\right)$ and from $\mathrm{H}-2^{\prime}$ to $\mathrm{C}-4^{\prime}$ and $\mathrm{C}-5^{\prime}$ revealed the double bond of $\mathrm{C}-2^{\prime}$ and C-3'. Additionally, the HMBC correlations from $\mathrm{H}-2$ and $\mathrm{H}-2^{\prime}$ to $\mathrm{C}-\mathrm{1}^{\prime}\left(\delta_{\mathrm{C}} 190.7\right)$ indicated the presence of carbonyl at $\mathrm{C}-1^{\prime}$. Thus, the structure of compound 2 was designed as in Figure 1 and named $\Delta^{2^{\prime}}-1^{\prime}$-dehydropenicillide.

Compound $\mathbf{3}$ was isolated as a colorless powder. The molecular formula of $\mathbf{3}$ was determined to be $\mathrm{C}_{11} \mathrm{H}_{12} \mathrm{O}_{6}$ based on the HRESIMS spectrum $\left(\mathrm{m} / z[\mathrm{M}+\mathrm{H}]^{+}\right.$241.0705, calcd for $\mathrm{C}_{11} \mathrm{H}_{13} \mathrm{O}_{6}{ }^{+}, 241.0707$ ), accounting for six degrees of unsaturation (Supplementary Figure S17). The ${ }^{1} \mathrm{H}$ NMR data of 3 (Table 2 and Supplementary Figure S18) displayed one methine proton at $\delta_{\mathrm{H}} 6.31(1 \mathrm{H}, \mathrm{s}, \mathrm{H}-3)$, one methyl group at $\delta_{\mathrm{H}} 2.31(3 \mathrm{H}, \mathrm{H}-10)$, and two methoxyl groups at $\delta_{\mathrm{H}} 3.40(3 \mathrm{H}, \mathrm{s}, \mathrm{H}-8)$ and $3.74(1 \mathrm{H}, \mathrm{s}, \mathrm{H}-9)$ as well as two protons for hydroxyl groups at $\delta_{\mathrm{H}} 9.71(1 \mathrm{H}, \mathrm{s}, 4-\mathrm{OH})$ and $9.33(1 \mathrm{H}, \mathrm{s}, 6-\mathrm{OH})$. The ${ }^{13} \mathrm{C}$ and HSQC spectrum of 1 (Supplementary Figures S19 and S20) showed 11 carbon signals (Table 2), including one carboxyl at $\delta_{\mathrm{C}} 168.7$ (C-1); one acetal signal at $\delta_{\mathrm{C}} 100.5$ (C-3); six aromatic quaternary carbons at 122.5 (C-3a), 144.0 (C-4), 141.0 (C-5), 151.1 (C-6), 116.1 (C-7), and 119.0 (C-7a); one methyl group at $\delta_{\mathrm{C}} 9.5$ (C-10); and two methoxyl groups at $\delta_{\mathrm{C}} 55.2(\mathrm{C}-8)$ and 60.3 (C-9). The NMR data revealed the phthalide analogue for compound 3 . The key HMBC correlations (Figure 2 and Supplementary Figure S21) from H-3 to C-8 and H-8 to $\mathrm{C}-3$ revealed the methoxyl group at $\mathrm{C}-3$. Additionally, the HMBC correlations from $\mathrm{H}-3$ to $\mathrm{C}-1, \mathrm{C}-4$, and C-7a demonstrated the lactone from C-7a, through C-1/O-2/C-3, to C-3a. The hydroxyl groups at C-4 and C-6 were identified by HMBC correlations from $\mathrm{H}-4-\mathrm{OH}$ to $\mathrm{C}-3 \mathrm{a}, \mathrm{C}-4$, and $\mathrm{C}-5$ and from $\mathrm{H}-6-\mathrm{OH}$ to $\mathrm{C}-5, \mathrm{C}-6$, and C-7. The methyl group at C-10 was confirmed by HMBC correlations from $\mathrm{H}-10$ to $\mathrm{C}-6, \mathrm{C}-7$, and $\mathrm{C}-7 \mathrm{a}$. The HMBC cross peak from $\mathrm{H}-9$ to $\mathrm{C}-5$ revealed the methoxyl group at $\mathrm{C}-9$ attached to $\mathrm{C}-5$. From 
the optical rotation, we used c 0.05 in $\mathrm{MeOH}$, and as the data undulated near zero, we could not establish if it was an enantiomeric or racemic form. Based on the analogue of 3-methoxyepicoccone [25], compound $\mathbf{3}$ was named 5-methyl-3-methoxyepicoccone.

Table 2. ${ }^{1} \mathrm{H}(500 \mathrm{MHz})$ and ${ }^{13} \mathrm{C}(125 \mathrm{MHz})$ NMR data of 3 and 4.

\begin{tabular}{|c|c|c|c|c|}
\hline \multirow{2}{*}{ Position } & \multicolumn{2}{|c|}{3 (DMSO- $\left.d_{6}\right)$} & \multicolumn{2}{|c|}{4 (DMSO- $\left.d_{6}\right)$} \\
\hline & $\delta_{C}$, Type & $\delta_{\mathrm{H}}(J$ in $\mathrm{Hz})$ & $\delta_{C}$, Type & $\delta_{\mathrm{H}}(J$ in $\mathrm{Hz})$ \\
\hline 1 & $168.7, \mathrm{C}$ & & $168.8, \mathrm{C}$ & \\
\hline 3 & $100.5, \mathrm{CH}$ & $6.31(\mathrm{~s})$ & 68.0, $\mathrm{CH}_{2}$ & $5.26(\mathrm{~s})$ \\
\hline $3 a$ & $122.5, \mathrm{C}$ & & $119.8, \mathrm{C}$ & \\
\hline 4 & $144.0, \mathrm{C}$ & & $150.7, \mathrm{C}$ & \\
\hline 5 & $141.0, \mathrm{C}$ & & $124.8, \mathrm{C}$ & \\
\hline 6 & 151.1, C & & $155.9, \mathrm{C}$ & \\
\hline 7 & 116.1, C & & 118.7, C & \\
\hline $7 a$ & 119.0, C & & $128.8, \mathrm{C}$ & \\
\hline 8 & $55.2, \mathrm{CH}_{3}$ & $3.40(\mathrm{~s})$ & $9.8, \mathrm{CH}_{3}$ & $2.16(\mathrm{~s})$ \\
\hline 9 & $60.3, \mathrm{CH}_{3}$ & $3.74(\mathrm{~s})$ & $61.8, \mathrm{CH}_{3}$ & $3.73(\mathrm{~s})$ \\
\hline 10 & $9.5, \mathrm{CH}_{3}$ & $2.31(\mathrm{~s})$ & $166.4, \mathrm{C}$ & \\
\hline $4-\mathrm{OH}$ & & $9.71(\mathrm{~s})$ & & \\
\hline $6-\mathrm{OH}$ & & 9.33 (s) & & \\
\hline
\end{tabular}

Compound 4 was isolated as a colorless powder. The molecular formula of 4 was determined to be $\mathrm{C}_{11} \mathrm{H}_{10} \mathrm{O}_{6}$ based on the HRESIMS spectrum $\left(\mathrm{m} / \mathrm{z}[\mathrm{M}+\mathrm{H}]^{+} 239.0554\right.$, calcd for $\mathrm{C}_{11} \mathrm{H}_{11} \mathrm{O}_{6}{ }^{+}, 239.0550$ ), accounting for seven degrees of unsaturation (Supplementary Figure S23). The ${ }^{1} \mathrm{H}$ NMR data of 4 (Table 2 and Supplementary Figure S24) displayed one oxygenated methylene group at $\delta_{\mathrm{H}} 5.26(2 \mathrm{H}, \mathrm{s}, \mathrm{H}-3)$, one methyl group at $\delta_{\mathrm{H}} 2.16(3 \mathrm{H}$, $\mathrm{H}-8)$, and one methoxyl groups at $\delta_{\mathrm{H}} 3.73(3 \mathrm{H}, \mathrm{s}, \mathrm{H}-9)$. The ${ }^{13} \mathrm{C}$ and HSQC spectrum of 1 (Supplementary Figures S25 and S26) showed 11 carbons signals (Table 2), including two carboxyl groups at $\delta_{\mathrm{C}} 168.8$ (C-1) and 166.4 (C-10); one oxygenated methylene group at $\delta_{\mathrm{C}} 68.0$ (C-3); six quaternary carbons at 119.8 (C-3a), 150.7 (C-4), 124.8 (C-5), 155.9 (C-6), 118.7 (C-7), and 128.8 (C-7a); one methyl group at $\delta_{\mathrm{C}} 9.8$ (C-8); and one methoxyl group at $\delta_{\mathrm{C}} 61.8$ (C-9). In combination with the HMBC correlations (Figure 2 and Supplementary Figure S27) from H-3 to C-1, C-4, and C-7a; from H-8 to C-4, C-5, and C-6; and from H-9 to C-6, compound 4 was identified as an analogue of phthalide [25] and named 7-carboxy-4hydroxy-6-methoxy-5-methylphthalide.

Four known secondary metabolites were isolated from Aspergillus sp. IMCASMF180035, with three of them identified as yicathin C (5) [26], 3-methoxyepicoccone (7) [27], 4-hydroxy6-methoxy-5-methylphthalide (8) [28], by comparing the spectroscopic data with each of the reported data. $1^{\prime}$-dehydroxypenicillide (6) was characterized by comparing the spectroscopic data with the reported structure and related analogues [24,29].

\subsection{Biological Activity}

All of the compounds were subjected to antibacterial assays against $S$. aureus ATCC 25923, methicillin-resistant S. aureus USA300, E. coli ATCC 11775, E. faecium ATCC 19434, P. aeruginosa PAO1, and H. pylori G27. Compound 1 exhibited significant antibacterial activities against $S$. aureus and methicillin-resistant $S$. aureus (MRSA), with MIC values of 5.60 and $22.40 \mathrm{mM}$, respectively (positive control, vancomycin, MIC $=0.35 \mathrm{mM}$ ). The compounds containing xanthone or anthracenone moieties showed antibacterial activities against a panel of pathogens $[13,30,31]$. Compound 1 was the first natural product containing a specific carbon skeleton with a spiro-ring system of xanthene and anthracenone, which may offer the antibacterial activities against drug-sensitive and -resistant $S$. aureus strains. Compounds $\mathbf{2}$ and $\mathbf{6}$ exhibited potent antibacterial activities against H. pylori, with MIC values of 21.73 and $21.61 \mathrm{mM}$, respectively (positive control, metronidazole, MIC $=11.68 \mathrm{mM}$ ). 


\section{Materials and Methods}

\subsection{General Experimental Procedures}

Optical rotations $\left([\alpha]_{D}\right)$ were recorded on an Anton Paar MCP 200 Modular Circular Polarimeter (Austria) in a $100 \times 2 \mathrm{~mm}$ cell at $22{ }^{\circ} \mathrm{C}$. One-dimensional and two-dimensional NMR spectra were measured at $25{ }^{\circ} \mathrm{C}$ using a Bruker Avance 500 spectrometer with residual solvent peaks as references (DMSO- $d_{6}: \delta_{\mathrm{H}} 2.50, \delta_{\mathrm{C}} 39.52 ; \mathrm{CDCl}_{3}: \delta_{\mathrm{H}} 7.26, \delta_{\mathrm{C}} 77.16$ ). high-resolution electrospray ionization mass spectrometry (HRESIMS) measurements were obtained on an Accurate-Mass-Q-TOF LC/MS 6520 instrument (Santa Clara, CA, USA) in positive ion mode. HPLC was performed using an Agilent 1200 Series HPLC System equipped with a diode array detector, a fraction collector, and an Agilent ZORBAX Eclipse XDB-C8 column $(250 \times 9.4 \mathrm{~mm}, 5 \mu \mathrm{m})$.

\subsection{Microbial Material}

Strain IMCAS180035 was isolated from a mud sample collected from the intertidal zones of the Yellow Sea in Qingdao, China, and grown on a potato dextrose agar plate at $28^{\circ} \mathrm{C}$. This strain was identified as Aspergillus sp. based on gene sequence analysis of the internal transcribed spacer (ITS) (Supplementary Figure S29) using a conventional primer pair of ITS4 (5'-TCCTCCGCTTATTGATATGC-3') and ITS5 (5'-GGAAGTAAAAGTCGTAACAAGG-3'). The strain was deposited in the China General Microbiological Culture Collection Center (CGMCC No. 3.20170), Beijing, China, with the GenBank (NCBI) accession number MW015145.

\subsection{Fermentation, Extraction, and Purification}

The spore of Aspergillus sp. IMCASMF180035 stored in $-80^{\circ} \mathrm{C}$ was inoculated on a potato dextrose agar plate and incubated at $28{ }^{\circ} \mathrm{C}$ for 7 days; then, the fungal colony was cut into $1 \mathrm{~cm}^{2}$ with a sterilized knife and placed into ten $1 \mathrm{~L}$ conical flasks, each containing a solid medium consisting of $200 \mathrm{~g}$ of rice and $150 \mathrm{~mL}$ of distilled water. The inoculated flasks were incubated stationary at $28^{\circ} \mathrm{C}$ for 30 days. The cultures and medium of Aspergillus sp. IMCASMF180035 were extracted three times by EtOAc:MeOH (80:20), and the combined extracts were reduced to dryness in vacuo to yield brown residue. The residue was resuspended into $500 \mathrm{~mL}$ of distilled water and partitioned by EtOAc. Then, the EtOAc layer was dried in vacuo to yield a dark residue $(4.68 \mathrm{~g})$. The EtOAc fraction was subjected to reduced pressure silica gel chromatography $(50 \times 70 \mathrm{~mm}$ column, TLC $\mathrm{H}$ silica) using a stepwise gradient of $80-100 \%$ hexane $/ \mathrm{CH}_{2} \mathrm{Cl}_{2}$ and then $0-90 \% \mathrm{MeOH} / \mathrm{CH}_{2} \mathrm{Cl}_{2}$ to afford 15 fractions. Fraction $\mathrm{F}$ was purified on a Sephadex LH20 column using an elution of $\mathrm{CH}_{2} \mathrm{Cl}_{2}: \mathrm{MeOH}$ (2:1) to give five subfractions, and $\mathrm{F} 3$ was further separated by HPLC (Agilent ZORBAX Eclipse XDB-C8, $250 \times 9.4 \mathrm{~mm}, 5 \mu \mathrm{m}$ column, $3.0 \mathrm{tmL} / \mathrm{min}$ ), eluting with $75 \% \mathrm{MeOH} / \mathrm{H}_{2} \mathrm{O}$ to yield compound 6 ( $3.2 \mathrm{mg}$ ). Fraction $\mathrm{G}$ was fractionated on a Sephadex $\mathrm{LH}-20$ column using an elution of $\mathrm{CH}_{2} \mathrm{Cl}_{2}: \mathrm{MeOH}(2: 1)$ to give four subfractions (G1-G4). G2 was further purified by HPLC (Agilent ZORBAX Eclipse XDB-C $8,250 \times 9.4 \mathrm{~mm}, 5 \mu \mathrm{m}$ column, $3.0 \mathrm{~mL} / \mathrm{min}$ ), eluting by $70 \% \mathrm{MeOH} / \mathrm{H}_{2} \mathrm{O}$ to yield compounds $2(1.5 \mathrm{mg}), 3(1.2 \mathrm{mg})$, and $7(1.0 \mathrm{mg})$. Fraction J was subjected to a Sephadex LH-20 column using an elution of $\mathrm{CH}_{2} \mathrm{Cl}_{2}: \mathrm{MeOH}$ (2:1) to give nine subfractions (J1-J9). J8 was further fractionated by HPLC (Agilent ZORBAX Eclipse XDB-C8, $250 \times 9.4 \mathrm{~mm}$, $5 \mu \mathrm{m}$ column, $3.0 \mathrm{~mL} / \mathrm{min})$, eluting with $65 \% \mathrm{MeOH} / \mathrm{H}_{2} \mathrm{O}$ to yield compounds $4(1.1 \mathrm{mg})$ and 8 (2.3 mg). Fraction $\mathrm{N}$ was subjected to a Sephadex LH-20 column using an elution of $\mathrm{CH}_{2} \mathrm{Cl}_{2}: \mathrm{MeOH}(2: 1)$ to give ten subfractions (N1-N10). N8 was further purified by HPLC (Agilent ZORBAX Eclipse XDB-C8, $250 \times 9.4 \mathrm{~mm}, 5 \mu \mathrm{m}$ column, $3.0 \mathrm{~mL} / \mathrm{min}$ ), eluting by $65 \% \mathrm{MeOH} / \mathrm{H}_{2} \mathrm{O}$ to yield compounds $1(2.1 \mathrm{mg})$ and $5(5.1 \mathrm{mg})$. All the new compounds were analyzed at the same condition to check the purity and compare the retention time (Supplementary Figures S9, S16, S22 and S28). 


\subsubsection{Aspergiloxathene A (1)}

Aspergiloxathene A (1): Light yellow powder; ${ }^{1} \mathrm{H}$ and ${ }^{13} \mathrm{C}$ NMR data, Table 1; HRESIMS m/z 559.1235 [M + H] ${ }^{+}\left(\right.$calcd $\left.\mathrm{C}_{30} \mathrm{H}_{22} \mathrm{O}_{11}, 559.1235\right)$.

\subsection{2. $\Delta 2^{\prime}-1^{\prime}$-dehydropenicillide (2)}

$\Delta^{2^{\prime}}-1^{\prime}$-dehydropenicillide (2): Light yellow powder; ${ }^{1} \mathrm{H}$ and ${ }^{13} \mathrm{C}$ NMR data, Table 1; HRESIMS $m / z 369.1330[\mathrm{M}+\mathrm{H}]^{+}$(calcd for $\mathrm{C}_{21} \mathrm{H}_{21} \mathrm{O}_{6}, 369.1333$ ).

\subsubsection{5-methyl-3-methoxyepicoccone (3)}

5-methyl-3-methoxyepicoccone (3): Colorless powder; ${ }^{1} \mathrm{H}$ and ${ }^{13} \mathrm{C}$ NMR data, Table 2; HRESIMS $m / z 241.0705[\mathrm{M}+\mathrm{H}]^{+}$(calcd for $\mathrm{C}_{30} \mathrm{H}_{23} \mathrm{O}_{11}, \mathrm{C}_{11} \mathrm{H}_{13} \mathrm{O}_{6}, 241.0707$ ).

\subsubsection{7-carboxy-4-hydroxy-6-methoxy-5-methylphthalide (4)}

7-carboxy-4-hydroxy-6-methoxy-5-methylphthalide (4): Colorless powder; ${ }^{1} \mathrm{H}$ and ${ }^{13} \mathrm{C}$ NMR data, Table 2; HRESIMS $\mathrm{m} / z 239.0554[\mathrm{M}+\mathrm{H}]^{+}$(calcd for $\mathrm{C}_{11} \mathrm{H}_{11} \mathrm{O}_{6}, 239.0550$ ).

\subsection{Antibacterial Activity Assays}

The microbial inhibition assays were carried out according to the Antimicrobial Susceptibility Testing Standards outlined by the Clinical and Laboratory Standards Institute document M07-A7 (CLSI) [32] by using a penal of pathogens of S. aureus ATCC 25923, MRSA USA300, E. coli ATCC 11775, E. faecium ATCC 19434, P. aeruginosa PAO1, and $H$. pylori G27. Briefly, the bacteria (S. aureus, MRSA, E. coli, E. faecium, and P. aeruginosa) were taken out from glycerol stocks and inoculated on lysogeny broth (LB) agar plate and cultured overnight at $37^{\circ} \mathrm{C}$. Then, single colonies were picked from the agar plates and adjusted to approximately $10^{4}$ colony-forming unit (CFU) $/ \mathrm{mL}$ with Mueller-Hinton Broth. Two microliters of 2-fold serial dilution of each compound (in DMSO) were added to each row on a 96-well microplate containing $100 \mu \mathrm{L}$ of bacterial suspension in each well. Vancomycin and ciprofloxacin were used as positive controls, and DMSO was used as a negative control. The 96-well plate was incubated at $37^{\circ} \mathrm{C}$ aerobically for $24 \mathrm{~h}$. Anti- $H$. pylori (G27) was prepared in a 96-well microtiter plate containing $100 \mu \mathrm{L}$ of Brain Heart Infusion (BHI) broth supplemented with 10\% fetal calf serum (FCS). Metronidazole was used as a positive control. The liquid culture of 2-day-old H. pylori was diluted 10 times in $\mathrm{BHI}$ broth to yield a final concentration of $5 \times 10^{5}$ to $1 \times 10^{6} \mathrm{CFU} / \mathrm{mL}$. Two microliters of 2-fold serial dilution of each compound (in DMSO) were added into each well of the testing plates. The testing plates were incubated in a microaerophilic atmosphere at $37^{\circ} \mathrm{C}$ for 3 days. The MIC was determined to be the lowest concentration, which resulted in no visible turbidity $[33,34]$.

\section{Conclusions}

This study reported the chemical investigation on the marine-derived fungus Aspergillus sp. IMCASMF180035, which resulted in the isolation and characterization of eight natural products, including one dimeric anthroquinone, aspergiloxathene A (1); one penicillide analogue, $\Delta^{2^{\prime}}-1^{\prime}$-dehydropenicillide (2); and two new phthalide derivatives, 5methyl-3-methoxyepicoccone (3) and 7-carboxy-4-hydroxy-6-methoxy-5-methylphthalide (4), together with four known compounds, yicathin C (5), 1'-dehydropenicillide (6), 3methoxyepicoccone (7), and 4-hydroxy-6-methoxy-5-methylphthalide (8). To our best knowledge, compound 1 was the first natural structure with xanthene and anthracenone moieties with an unprecedented carbon skeleton with a spiro-ring system. All the isolated compounds were evaluated against a panel of bacteria, such as $S$. aureus, methicillinresistant S. aureus, E. coli, E. faecium, P. aeruginos, and H. pylori. Compound 1 displayed potential antibacterial activity against $S$. aureus and MRSA, with MIC values of 5.60 and $22.40 \mathrm{mM}$, respectively. The difference in MICs between $S$. aureus and MRSA may due to the broad spectrum drug resistance of MRSA strain USA 300 to different classes of antibiotics, such as erythromycin, levofloxacin, clindamycin, tetracycline, and azithromycin $[35,36]$. 
Compounds 2 and $\mathbf{6}$ exhibited moderate antibacterial activities against $H$. pylori, with MIC values of 21.73 and $21.61 \mathrm{mM}$, respectively.

Supplementary Materials: The following are available online at https:/ /www.mdpi.com/article/10 .3390/antibiotics10040377/s1, Figures S1-S28: HRESIMS, 1D and 2D NMR, and HPLC profile for compounds 1-4, Figure S29: Neighbor-joining phylogenetic tree of IMCASMF180035.

Author Contributions: Data curation, F.S., R.L., N.Y., J.J., S.W., J.H., J.L., H.B., and X.X.; funding acquisition, F.S.; investigation, F.S., R.L., N.Y., J.J., S.W., J.H., J.L., H.B., and X.X.; supervision, F.S. and X.X.; writing—original draft, F.S.; writing—review and editing, F.S., R.L., N.Y., J.J., S.W., J.H., J.L., H.B., and X.X. All authors have read and agreed to the published version of the manuscript.

Funding: This work was supported by grants from the National Key R\&D Program of China (2018YFC0311000), the Key Lab of Marine Bioactive Substance and Modern Analytical Technique, SOA (MBSMAT-2019-06), the National Natural Science Foundation of China (81973204), and Research Foundation for Advanced Talents of Beijing Technology and Business University (No. 19008020158).

Institutional Review Board Statement: Not applicable.

Informed Consent Statement: Not applicable.

Data Availability Statement: The data are contained within the text.

Conflicts of Interest: The authors declare no conflict of interest.

\section{References}

1. Boucher, H.W.; Talbot, G.H.; Bradley, J.S.; Edwards, J.E.; Gilbert, D.; Rice, L.B.; Scheld, M.; Spellberg, B.; Bartlett, J. Bad bugs, no drugs: No ESKAPE! an update from the infectious diseases society of America. Clin. Infect. Dis. 2009, 48, 1-12. [CrossRef] [PubMed]

2. Kumarasamy, K.K.; Toleman, M.A.; Walsh, T.R.; Bagaria, J.; Butt, F.; Balakrishnan, R.; Chaudhary, U.; Doumith, M.; Giske, C.G.; Irfan, S.; et al. Emergence of a new antibiotic resistance mechanism in India, Pakistan, and the UK: A molecular, biological, and epidemiological study. Lancet. Infect. Dis. 2010, 10, 597-602. [CrossRef]

3. Wang, Y.; Zhang, R.; Li, J.; Wu, Z.; Yin, W.; Schwarz, S.; Tyrrell, J.M.; Zheng, Y.; Wang, S.; Shen, Z.; et al. Comprehensive resistome analysis reveals the prevalence of NDM and MCR-1 in Chinese poultry production. Nat. Microbiol. 2017, 2, 16260. [CrossRef]

4. Moloney, M.G. Natural products as a source for novel antibiotics. Trends. Pharmacol. Sci. 2016, 37, 689-701. [CrossRef]

5. Molinski, T.F.; Dalisay, D.S.; Lievens, S.L.; Saludes, J.P. Drug development from marine natural products. Nat. Rev. Drug. Discov. 2009, 8, 69-85. [CrossRef]

6. Shinde, P.; Banerjee, P.; Mandhare, A. Marine natural products as source of new drugs: A patent review (2015-2018). Expert Opin. Ther. Pat. 2019, 29, 283-309. [CrossRef]

7. Wiese, J.; Imhoff, J.F. Marine bacteria and fungi as promising source for new antibiotics. Drug Develop. Res. 2019, 80, 24-27. [CrossRef]

8. Blunt, J.W.; Carroll, A.R.; Copp, B.R.; Davis, R.A.; Keyzers, R.A.; Prinsep, M.R. Marine natural products. Nat. Prod. Rep. 2018, 35, 8-53. [CrossRef]

9. Carroll, A.R.; Copp, B.R.; Davis, R.A.; Keyzers, R.A.; Prinsep, M.R. Marine natural products. Nat. Prod. Rep. 2019, 36, 122-173. [CrossRef]

10. Carroll, A.R.; Copp, B.R.; Davis, R.A.; Keyzers, R.A.; Prinsep, M.R. Marine natural products. Nat. Prod. Rep. 2020, 37, 175-223. [CrossRef]

11. Song, F.; Liu, X.; Guo, H.; Ren, B.; Chen, C.; Piggott, A.; Yu, K.; Gao, H.; Wang, Q.; Liu, M.; et al. Brevianamides with antitubercular potential from a marine-derived isolate of Aspergillus versicolor. Org. lett. 2012, 14, 4770-4773. [CrossRef]

12. Song, F.; Ren, B.; Chen, C.; Yu, K.; Liu, X.; Zhang, Y.; Yang, N.; He, H.; Liu, X.; Dai, H.; et al. Three new sterigmatocystin analogues from marine-derived fungus Aspergillus versicolor MF359. Appl. Microbiol. Biot. 2014, 98, 3753-3758. [CrossRef]

13. Song, Z.; Gao, J.; Hu, J.; He, H.; Huang, P.; Zhang, L.; Song, F. One new xanthenone from the marine-derived fungus Aspergillus versicolor MF160003. Nat. Prod. Res. 2019, 34, 2907-2912. [CrossRef]

14. An, C.L.; Kong, F.D.; Ma, Q.Y.; Xie, Q.Y.; Yuan, J.Z.; Zhou, L.M.; Dai, H.F.; Yu, Z.F.; Zhao, Y.X. Chemical constituents of the marine-derived fungus Aspergillus sp. SCS-KFD66. Mar. Drugs 2018, 16, 468. [CrossRef]

15. Li, D.; Xu, Y.; Shao, C.L.; Yang, R.Y.; Zheng, C.J.; Chen, Y.; Fu, X.M.; Qian, P.Y.; She, Z.G.; de Voogd, N.J.; et al. Antibacterial bisabolane-type sesquiterpenoids from the sponge-derived fungus Aspergillus sp. Mar. Drugs 2012, 10, 234-241. [CrossRef]

16. Prompanya, C.; Dethoup, T.; Bessa, L.J.; Pinto, M.M.; Gales, L.; Costa, P.M.; Silva, A.M.; Kijjoa, A. New isocoumarin derivatives and meroterpenoids from the marine sponge-associated fungus Aspergillus similanensis sp. nov. KUFA 0013. Mar. Drugs 2014, 12, 5160-5173. [CrossRef]

17. Wu, J.S.; Shi, X.H.; Yao, G.S.; Shao, C.L.; Fu, X.M.; Zhang, X.L.; Guan, H.S.; Wang, C.Y. New thiodiketopiperazine and 3,4dihydroisocoumarin derivatives from the marine-derived fungus Aspergillus terreus. Mar. Drugs 2020, 18, 132. [CrossRef] 
18. Ding, L.; Ren, L.; Li, S.; Song, J.; Han, Z.; He, S.; Xu, S. Production of new antibacterial 4-hydroxy- $\alpha$-pyrones by a marine fungus Aspergillus niger cultivated in solid medium. Mar. Drugs 2019, 17, 344. [CrossRef]

19. Choi, B.K.; Cho, D.Y.; Choi, D.K.; Trinh, P.T.H.; Shin, H.J. Two new phomaligols from the marine-derived fungus Aspergillus flocculosus and their anti-neuroinflammatory activity in BV-2 microglial cells. Mar. Drugs 2021, 19, 65. [CrossRef]

20. Wang, Z.; Jia, J.; Wang, L.; Li, F.; Wang, Y.; Jiang, Y.; Song, X.; Qin, S.; Zheng, K.; Ye, J.; et al. Anti-HSV-1 activity of Aspergillipeptide D, a cyclic pentapepetide isolated from fungus Aspergillus sp. SCSIO 41501. Virol. J. 2020, 17, 41. [CrossRef]

21. Ding, Y.; Zhu, X.; Hao, L.; Zhao, M.; Hua, Q.; An, F. Bioactive indolyl diketopiperazines from the marine derived endophytic Aspergillus versicolor DY180635. Mar. Drugs 2020, 18, 338. [CrossRef]

22. Liu, Y.F.; Yue, Y.F.; Feng, L.X.; Zhu, H.J.; Cao, F. Asperienes A-D, bioactive sesquiterpenes from the marine-derived fungus Aspergillus flavus. Mar. Drugs 2019, 17, 550. [CrossRef]

23. Bae, S.Y.; Liao, L.; Park, S.H.; Kim, W.K.; Shin, J.; Lee, S.K. Antitumor activity of Asperphenin A, a lipopeptidyl benzophenone from marine-derived Aspergillus sp. fungus, by inhibiting yubulin polymerization in colon cancer cells. Mar. Drugs 2020, 18, 110. [CrossRef] [PubMed]

24. Komai, S.I.; Hosoe, T.; Itabashi, T.; Nozawa, K.; Yaguchi, T.; Fukushima, K.; Kawai, K.I. New penicillide derivatives isolated from Penicillium simplicissimum. J. Nat. Med. 2006, 60, 185-190. [CrossRef] [PubMed]

25. El Amrani, M.; Lai, D.; Debbab, A.; Aly, A.H.; Siems, K.; Seidel, C.; Schnekenburger, M.; Gaigneaux, A.; Diederich, M.; Feger, D.; et al. Protein kinase and HDAC inhibitors from the endophytic fungus Epicoccum nigrum. J. Nat. Prod. 2014, 77, 49-56. [CrossRef] [PubMed]

26. Sun, R.R.; Miao, F.P.; Zhang, J.; Wang, G.; Yin, X.L.; Ji, N.Y. Three new xanthone derivatives from an algicolous isolate of Aspergillus wentii. Magn. Reson. Chem. 2013, 51, 65-68. [CrossRef]

27. Achenbach, H.; Mühlenfeld, A.; Brillinger, G.U. Phthalide und chromanole aus Aspergillus duricaulis. Liebigs Ann. der Chem. 1985, 1985, 1596-1628. [CrossRef]

28. Li, W.; Yang, X.; Yang, Y.; Duang, R.; Chen, G.; Li, X.; Li, Q.; Qin, S.; Li, S.; Zhao, L.; et al. Anti-phytopathogen, multi-target acetylcholinesterase inhibitory and antioxidant activities of metabolites from endophytic Chaetomium globosum. Nat. Prod. Res. 2016, 30, 2616-2619. [CrossRef]

29. Salituro, G.M.; Pettibone, D.J.; Clineschmidt, B.V.; Williamson, J.M.; Zink, D.L. Potent, non-peptidic oxytocin receptor antagonists from a natural source. Bioorg. Med. Chem. Lett. 1993, 3, 337-340. [CrossRef]

30. Loureiro, D.R.P.; Soares, J.X.; Costa, J.C.; Magalhaes, A.F.; Azevedo, C.M.G.; Pinto, M.M.M.; Afonso, C.M.M. Structures, activities and drug-likeness of anti-infective xanthone derivatives isolated from the marine environment: A Review. Molecules 2019, 24, 243. [CrossRef]

31. Coopoosamy, R.M.; Magwa, M.L. Antibacterial activity of aloe emodin and aloin A isolated from Aloe excelsa. Afr. J. Biotechnol. 2006, 5, 1092-1094.

32. Clinical and Laboratory Standards Institute. Methods for Dilution Antimicrobial Susceptibility Tests for Bacteria that Grow Aerobically, Approved Standard, 7th ed.; Clinical and Laboratory Standards Institute: Wayne, PA, USA, 2008.

33. Han, J.; Yang, N.; Wei, S.; Jia, J.; Lin, R.; Li, J.; Bi, H.; Song, F.; Xu, X. Dimeric hexylitaconic acids from the marine-derived fungus Aspergillus welwitschiae CUGBMF180262. Nat. Prod. Res. 2020. [CrossRef] [PubMed]

34. Huang, Y.; Hang, X.; Jiang, X.; Zeng, L.; Jia, J.; Xie, Y.; Li, F.; Bi, H. In vitro and in vivo activities of zinc linolenate, a selective antibacterial agent against Helicobacter pylori. Antimicrob. Agents. Chemother. 2019, 63, e00004-19. [CrossRef] [PubMed]

35. Mnyambwa, N.P.; Mahende, C.; Wilfred, A.; Sandi, E.; Mgina, N.; Lubinza, C.; Kahwa, A.; Petrucka, P.; Mfinanga, S.; Ngadaya, E.; et al. Antibiotic susceptibility patterns of bacterial isolates from routine clinical specimens from Referral Hospitals in Tanzania: A prospective hospital-based observational study. Infect. Drug Resist. 2021, 4, 869-878. [CrossRef]

36. Luna, V.A.; Xu, Z.Q.; Eiznhamer, D.A.; Cannons, A.C.; Cattani, J. Susceptibility of 170 isolates of the USA300 clone of MRSA to macrolides, clindamycin and the novel ketolide cethromycin. J. Antimicrob. Chemother. 2008, 62, 639-940. [CrossRef] [PubMed] 